\title{
DIETARY INTAKE, NUTRITIONAL STATUS AND COGNITIVE PERFORMANCE AMONG FISHERMEN'S CHILDREN: A REVIEW
}

\author{
Atiah Munirah Meli and Asma' Ali \\ Department of Food Science, Faculty of Fisheries and Food Science, Universiti Malaysia Terengganu, 21030 Kuala \\ Nerus, Terengganu, Malaysia
}

Corresponding author: Asma' Ali

Email: asma.ali@umt.edu.my

\begin{abstract}
This paper highlights the dietary intake of fishermen's children, their nutritional status and cognitive performance. It will help to have a reasonable perspective of their dietary intake and their relationship with nutritional status and how it inevitably influences cognitive performance. This is relevant as it can provide the government and health authorities with insights into the execution of an action plan to improve the nutritional status of fishing communities, especially in Malaysia, where possible. A systematic search of the English scholarly papers on this subject was undertaken between 1997 and 2020. A total of 20 studies have been systematically chosen and reviewed. Studies are divided into two groups, based on the type of research conducted. Ten of the retrieved studies looked at dietary intake and nutritional status in fisherman's children, while another ten studies looked at cognitive performance in children and adolescents and the factors that contributed to it. In terms of dietary intake, three studies reported low energy consumption and low carbohydrate intake, one study reported high carbohydrate intake, four studies reported high protein intake, one study reported low fat intake, five studies reported low micronutrient intake (calcium, iron, vitamin A and vitamin C) and two studies reported high intake of niacin. As far as nutritional status is concerned, six studies recorded that children are stunted/underweight and three studies reported that children are obese/overweight. In comparison, one study recorded high cognitive performance, three studies reported average cognitive performance, and three studies reported poor cognitive performance. In the studies reviewed, it has been shown that there is a positive association between socio-economic status, dietary intake/nutritional status and cognitive performance among children in fishing communities in different regions. There is a need for nutrition education and intervention in these disadvantaged communities.
\end{abstract}

Keywords: Dietary intakes, Nutritional status, Cognitive Performance, Fishermen's children.

\section{INTRODUCTION}

Nutritional status refers to the condition of the human body influenced by the level of nutrients in the body and the ability of the level of nutrients to maintain the healthy body composition and function ${ }^{1}$. The nutritional status of an individual is influenced by several interrelated factors which include diet intake and physical activity. Malnutrition is a condition which results from imbalance in consumption of macronutrient and also micronutrient over a long period of time. Poor diet practices established during childhood have the potential to negatively impact growth of children and may increase the risk of diet related chronic disease such as obesity and cardiovascular diseases in later stages of life ${ }^{2-3}$. Aside from that, it also has an important and long-lasting influence on child cognitive development ${ }^{4}$. Adequate nutrients from diet are needed during the developmental stage for brain structure as well as function ${ }^{5}$. In addition to that, brain growth and development is most rapid and critical during the first 2 years of life, but development of the frontal lobes continues throughout early childhood ${ }^{4}$.

Nutritional status of fishermen children is one of the main concerns due to the vulnerability of fishermen households towards food security. Previous studies showed that food insecurity was prevalent among fishing communities ${ }^{6-8}$. Fishing is one of the important global industries, however it is also one of the sectors with the highest incidence of poverty 9 . Fishermen were used to characterize as having low socioeconomic status ${ }^{10-}$ 11 and poor standard of living ${ }^{12}$. Fishing communities depend on marine and coastal resources for their livelihood. Nevertheless, the fishing activities are susceptible to environmental changes such as rise of sea level, increased temperature on the sea surface and increased acidification of ocean which have reported to affect the abundance and distribution of fish species and also amount of fish caught by fishermen. Unpredictable fishing returns due to the environmental changes threaten their livelihood and may increase their vulnerability. Unlike the laborers from the other sectors, fishermen do not have monthly fixed income. Their income is primarily determined by the amount of fish caught through their fishing effort. Based on a study by Zainuddin et al. ${ }^{13}$, the majority of fishermen's households earned an income between USD 250 to USD 500 and others earned between USD 500 to USD 700 which did not pass the Malaysian median household income. A study by Nursyazwin \& Zein ${ }^{4}$ also stated that the 
level of fishermen's income is still far from the average national income per capita (MYR 3282) where their average earnings are between MYR 1853.47 to MYR 2595.39.

During monsoon season, the heavy rain and thunderstorm at the coast area and the rough and dangerous sea condition prevents the fishermen from fishing activities. Many of the fishermen at coastal areas begin to face financial problems in meeting their living needs during this period. According to Yaakob \& Chau $^{15}$, the mean income of fishermen in east coast of Peninsular Malaysia during monsoon period reduced around 9 to 32\% compared to normal period. Even though Malaysia government provides a monthly allowance of RM 200 to RM 300 for the fishermen, the allowance given is insufficient to cover the living expenses of the fishermen families, especially those whose children are still receiving education in school or university ${ }^{16}$. These cumulative pressures could produce significant consequences on household food security and susceptibility of the fishermen families especially the children to malnutrition. The decreased income level of fishermen increases the household vulnerability towards food insecurity ${ }^{7}$. Low-income level of fishermen constrained their purchasing power and decreased their household accessibility to healthy and nutritious food.

The objective of this study is to review previous studies on the nutritional status and dietary intake of the fishermen's children. Besides that, this study also reviewed the relationship between nutritional status, dietary intakes and cognitive development among the fishermen's children. The outcome from this study will help to provide better understanding on the nutritional status of the fishermen's children and identify gaps and deficiencies in previous work. This study will also contribute to the prioritization of research studies to address these gaps and implement policies and interventions aimed at improving the nutritional status of the fishing community.

\section{METHODS}

Identifying relevant studies

Studies published from 1997 to 2020 were searched from the electronic databases such as Science Direct, Taylor and Francis, Springer Link,
PubMed, Elsevier and open database such as Google Scholar. The key terms "nutritional status", “malnutrition”, “undernutrition”, "overnutrition", “dietary intake", “nutrient intake", "food intake" and "diet" combined with the terms "fishermen's children" and "fishing community" and "cognitive performance" and "cognitive function" in duplicates were used during the search. The references from the retrieved journals were also searched for additional related studies. The searches were restricted to academic journals published in English languages. All types of research studies were included in the search except review papers and systematic reviews.

\section{Study selection}

Cross sectional studies that involved children or adolescents aged below 18 years old from fishing communities were included in this review as well as studies that focused specifically on mother or caregiver-child pairs. Studies on adults in fishing communities and also non-healthy participants (i.e. serious illness, physical disability) were excluded from this review. The reviewed studies were carefully selected if the studies provide information about the nutritional status, dietary or nutrient intake of the children from fishing communities and since few studies found cognitive performance among such groups, similar studies on children were taken into account to show association of the nutritional status with cognitive performance. As a final result, 20 studies are selected for this review.

\section{Charting data}

Studies are grouped into two categories according to the type of investigation undertaken. Ten of the retrieved studies examined the dietary intake and nutritional status in fishermen's children while ten studies examined the cognitive performance in children and adolescents and factors contributing to it. The study location(s), author(s), year of publication, and objective(s) of study, number of participants, research instrument(s) and findings on the nutritional status and dietary intake of the fishermen's children were summarized in Table 1.0 while the association of nutritional status and other factors contributing to the cognitive performance were shown in Table 2.0. 
Table 1: Nutritional status and dietary intake of fishermen's children

\begin{tabular}{|c|c|c|c|c|c|c|}
\hline Study & $\begin{array}{c}\text { Study } \\
\text { Location }\end{array}$ & $\begin{array}{l}\text { Objective of the } \\
\text { study }\end{array}$ & $\begin{array}{c}\text { Study } \\
\text { population }\end{array}$ & $\begin{array}{c}\text { Research } \\
\text { Instrument }\end{array}$ & $\begin{array}{l}\text { Nutritional } \\
\text { Status }\end{array}$ & Dietary Intake \\
\hline $\begin{array}{l}\text { Murillo- } \\
\text { Castillo et } \\
\text { al. (2020) }\end{array}$ & $\begin{array}{l}\text { Kino Bay, a } \\
\text { fishing } \\
\text { community } \\
\text { located in } \\
\text { the } \\
\text { Northwest } \\
\text { of Mexico }\end{array}$ & $\begin{array}{l}\text { To determine if } \\
\text { food insecurity } \\
\text { was associated } \\
\text { with lower fruit } \\
\text { and vegetables } \\
\text { consumption and } \\
\text { overweight and } \\
\text { obesity in } \\
\text { children from } \\
\text { Mexican fishing } \\
\text { communities }\end{array}$ & $\begin{array}{l}100 \\
\text { elementary- } \\
\text { school } \\
\text { children aged } \\
\text { 6-12 years }\end{array}$ & $\begin{array}{l}\text { Anthropometric } \\
\text { measurements } \\
\text { (wt. and ht.), } \\
\text { Food frequency } \\
\text { questionnaire } \\
\text { of fruits and } \\
\text { vegetables, } \\
\text { The Mexican } \\
\text { Scale of Food } \\
\text { Security }\end{array}$ & $\begin{array}{c}\text { Overweight: } \\
25 \% \\
\text { Obese: } 24 \% \\
\text { Severely } \\
\text { obese: } 8 \%\end{array}$ & $\begin{array}{c}\text { Lower } \\
\text { consumption of } \\
\text { fruits and } \\
\text { vegetables }\end{array}$ \\
\hline $\begin{array}{l}\text { Gibson et } \\
\text { al. (2020) }\end{array}$ & $\begin{array}{l}\text { Komodo } \\
\text { District, } \\
\text { West } \\
\text { Manggarai } \\
\text { Regency, } \\
\text { Indonesia }\end{array}$ & $\begin{array}{l}\text { To investigate } \\
\text { the contribution } \\
\text { of fish and small- } \\
\text { scale coastal } \\
\text { fisheries } \\
\text { livelihood } \\
\text { activities to food } \\
\text { and nutrition } \\
\text { security }\end{array}$ & $\begin{array}{c}\text { Sixty-six } \\
\text { households } \\
\text { participated } \\
\text { in the study }\end{array}$ & $\begin{array}{c}\text { Household } \\
\text { survey, Focus } \\
\text { groups } \\
\text { discussions, } \\
\text { Semi- } \\
\text { structured } \\
\text { interviews, } \\
\text { Market survey, } \\
\text { Anthropometric } \\
\text { measurements } \\
\text { (wt. and ht.) }\end{array}$ & Stunting: $50 \%$ & $\begin{array}{c}\text {-High } \\
\text { consumption of } \\
\text { fish } \\
\text {-Low } \\
\text { consumption of } \\
\text { vitamin A rich } \\
\text { fruit \& } \\
\text { vegetables } \\
\text {-High } \\
\text { consumption of } \\
\text { sweet and } \\
\text { savoury snack }\end{array}$ \\
\hline $\begin{array}{l}\text { Capanzana } \\
\text { et al. } \\
(2018)\end{array}$ & Philippines & $\begin{array}{l}\text { To analyse the } \\
\text { nutritional status } \\
\text { of Filipino } \\
\text { children ages } 0- \\
60 \text { months ( } 0-5.0 \\
\text { years old) and } \\
61-120 \text { months } \\
(5.08-10.0 \text { years } \\
\text { old) in } \\
\text { households } \\
\text { headed by } \\
\text { fisherfolks }\end{array}$ & $\begin{array}{c}3,423 \text { young } \\
\text { children and } \\
16,398 \text { school } \\
\text { children } \\
\text { participants }\end{array}$ & $\begin{array}{l}\text { Anthropometric } \\
\text { measurements } \\
\text { (wt. and ht.) }\end{array}$ & $\begin{array}{c}\text { Underweight: } \\
19.9 \% \\
\text { Stunting: } \\
30.3 \% \\
\text { Wasting: } \\
7.9 \% \\
\text { Overweight: } \\
5 \%\end{array}$ & $\begin{array}{l}\text { No related } \\
\text { findings }\end{array}$ \\
\hline $\begin{array}{l}\text { Chua et } \\
\text { al. (2018) }\end{array}$ & $\begin{array}{l}\text { Terengganu, } \\
\text { Malaysia }\end{array}$ & $\begin{array}{c}\text { To assess diet } \\
\text { quality and its } \\
\text { association with } \\
\text { nutritional status } \\
\text { among } 7 \text { to } 12 \\
\text { years old } \\
\text { fishermen's } \\
\text { children in } \\
\text { Terengganu }\end{array}$ & $\begin{array}{c}100 \\
\text { fishermen's } \\
\text { children }\end{array}$ & $\begin{array}{l}\text { Questionnaire, } \\
\text { Anthropometric } \\
\text { measurements, } \\
\text { healthy eating } \\
\text { index (HEI) } \\
\text { through } 24-\mathrm{hr} \\
\text { diet recall }\end{array}$ & $\begin{array}{c}\text { Normal } \\
\text { weight: } 61 \%\end{array}$ & $\begin{array}{l}\text {-Low intake of } \\
\text { energy, } \\
\text { carbohydrates } \\
\text { and fats } \\
\text {-High intake of } \\
\text { protein } \\
\text {-Low intake of } \\
\text { calcium } \\
\text {-High intake of } \\
\text { iron, vitamin A } \\
\text { and C }\end{array}$ \\
\hline $\begin{array}{l}\text { Bandoh \& } \\
\text { Kenu } \\
(2017)\end{array}$ & $\begin{array}{l}\text { Ekumfi } \\
\text { Narkwa, } \\
\text { central } \\
\text { region of } \\
\text { Ghana }\end{array}$ & $\begin{array}{l}\text { To examine the } \\
\text { quality of food } \\
\text { consumed in } \\
\text { terms of nutrient } \\
\text { adequacy of } \\
\text { children in } \\
\text { fishing } \\
\text { community }\end{array}$ & $\begin{array}{c}250 \text { children } \\
\text { between } 6 \text { to } \\
59 \text { months }\end{array}$ & $\begin{array}{l}\text { Dietary } \\
\text { diversity } \\
\text { questionnaire, } \\
\text { Interview of } \\
\text { caregivers }\end{array}$ & $\begin{array}{l}\text { No related } \\
\text { findings }\end{array}$ & $\begin{array}{c}\text { Very low } \\
\text { consumption of } \\
\text { vitamin A rich } \\
\text { foods. High Iron } \\
\text { consumption } \\
\text { from fish }\end{array}$ \\
\hline $\begin{array}{l}\text { Baker- } \\
\text { French } \\
(2013)\end{array}$ & $\begin{array}{c}\text { Plurinational } \\
\text { State of } \\
\text { Bolivia }\end{array}$ & $\begin{array}{l}\text { To examine the } \\
\text { prevalence and } \\
\text { correlates of } \\
\text { household food } \\
\text { insecurity, } \\
\text { childhood } \\
\text { stunting and } \\
\text { maternal } \\
\text { overweight in } \\
\text { fisher } \\
\text { populations in } \\
\text { Bolivia's } \\
\text { Northern Amazon } \\
\text { Basin }\end{array}$ & $\begin{array}{l}304 \text { urban and } \\
327 \text { rural } \\
\text { households } \\
\text { with a head } \\
\text { female of } \\
\text { childbearing } \\
\text { age (15-49 } \\
\text { years) during } \\
\text { the low water } \\
\text { (October- } \\
\text { November) } \\
\text { and } 186 \text { urban } \\
\text { and } 297 \text { rural } \\
\text { households }\end{array}$ & $\begin{array}{l}\text { Anthropometric } \\
\text { measurement } \\
\text { (wt., ht.), } \\
\text { Household } \\
\text { Food Insecurity } \\
\text { Access } \\
\text { Scale, } \\
\text { Household } \\
\text { Hunger Scale, } \\
\text { Household } \\
\text { Dietary } \\
\text { Diversity Score }\end{array}$ & $\begin{array}{l}\text { Stunted: } \\
-34 \% \text { (urban) } \\
-42 \% \text { (rural) }\end{array}$ & $\begin{array}{c}\text { More than one- } \\
\text { quarter of } \\
\text { respondents did } \\
\text { not } \\
\text { consumed any } \\
\text { vegetables or } \\
\text { vitamin A rich } \\
\text { fruits or } \\
\text { vegetables in the } \\
\text { specified period }\end{array}$ \\
\hline
\end{tabular}




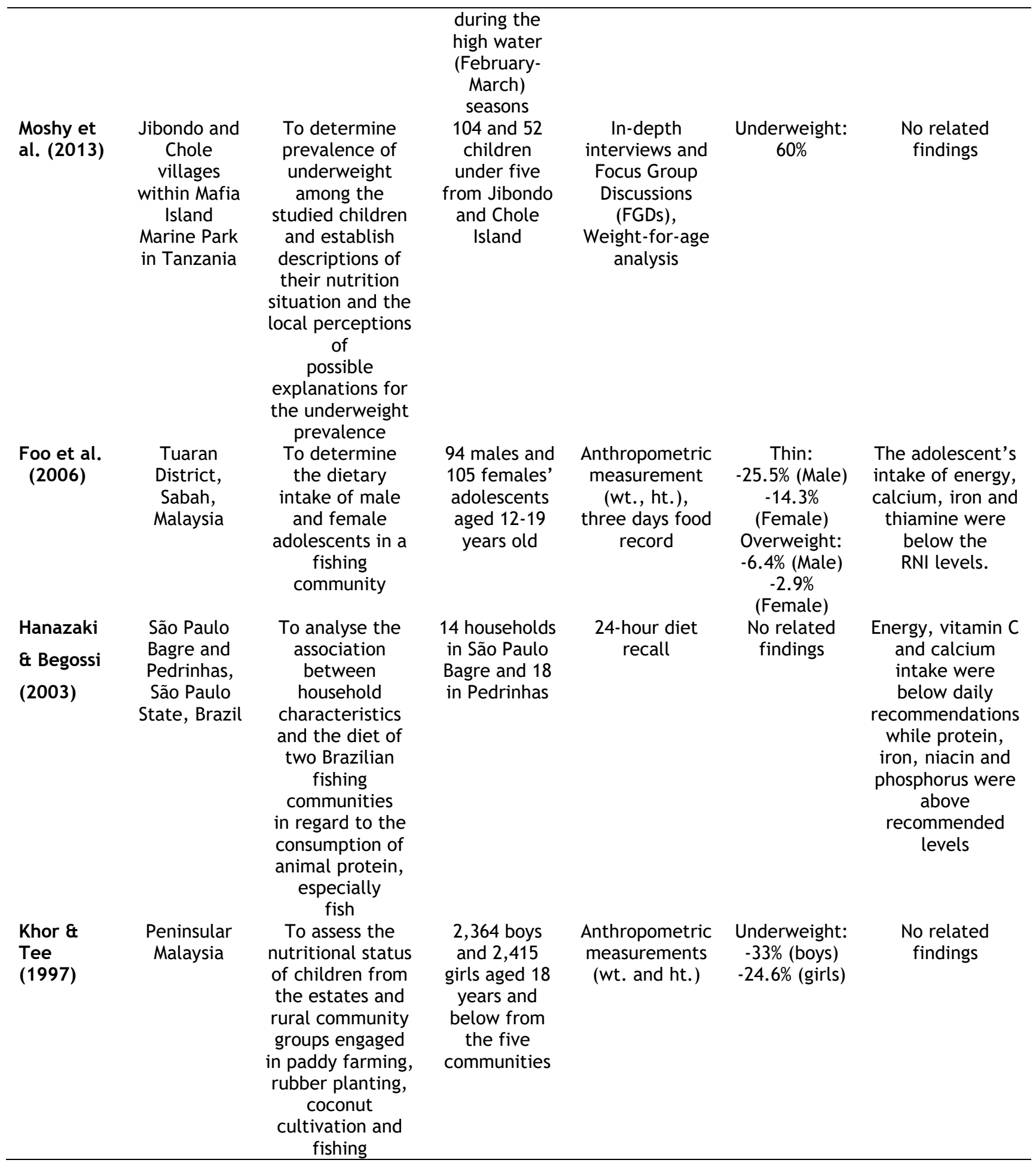

wt. = weight, ht. = height

$\mathrm{RNI}=$ Recommended Nutrient Intakes for Malaysia 
Table 2.0: Cognitive in children and adolescents and factors associating to the performance

\begin{tabular}{|c|c|c|c|c|c|c|}
\hline Study & $\begin{array}{l}\text { Study } \\
\text { Location }\end{array}$ & $\begin{array}{l}\text { Objective of the } \\
\text { study }\end{array}$ & $\begin{array}{c}\text { Study } \\
\text { population }\end{array}$ & $\begin{array}{l}\text { Research } \\
\text { Instrument }\end{array}$ & $\begin{array}{l}\text { Cognitive } \\
\text { performance }\end{array}$ & $\begin{array}{l}\text { Contributing } \\
\text { factors }\end{array}$ \\
\hline $\begin{array}{c}\text { Demetrio } \\
\text { u et al. } \\
(2020)\end{array}$ & $\begin{array}{c}\text { Major } \\
\text { Thessaloniki } \\
\text { area, } \\
\text { Greece }\end{array}$ & $\begin{array}{l}\text { To explore } \\
\text { relations } \\
\text { between } \\
\text { academic } \\
\text { performance, } \\
\text { cognition, } \\
\text { cognition self- } \\
\text { evaluation and } \\
\text { self- } \\
\text { representation }\end{array}$ & $\begin{array}{c}408 \\
\text { participants } \\
\text { from three } \\
\text { SES group } \\
\text { according to } \\
\text { parent's } \\
\text { education }\end{array}$ & $\begin{array}{l}\text { Socio-economic } \\
\text { status, } \\
\text { academic } \\
\text { achievements } \\
\text { and Cognitive } \\
\text { batteries }\end{array}$ & $\begin{array}{l}\text { Performance } \\
\text { varied as a } \\
\text { function of } \\
\text { tasks difficulty }\end{array}$ & $\begin{array}{l}\text { Cognitive } \\
\text { development } \\
\text { positively } \\
\text { contributes to } \\
\text { school } \\
\text { achievement } \\
\text { instead }\end{array}$ \\
\hline $\begin{array}{l}\text { Nurliyana } \\
\text { et al. } \\
(2020)\end{array}$ & $\begin{array}{l}\text { Seremban, } \\
\text { Negeri } \\
\text { Sembilan, } \\
\text { Malaysia }\end{array}$ & $\begin{array}{l}\text { To determine } \\
\text { the influence of } \\
\text { linear growth } \\
\text { and home } \\
\text { environment } \\
\text { towards } \\
\text { cognitive } \\
\text { development in } \\
\text { the first year of } \\
\text { Malaysian infants }\end{array}$ & $\begin{array}{l}151 \text { infants } \\
\text { and mothers }\end{array}$ & $\begin{array}{l}\text { Sociodemograph } \\
\text { ic, } \\
\text { anthropometry } \\
\text { (birth wt., wt. } \\
\text { and length), } \\
\text { home } \\
\text { environment, } \\
\text { Bayley-III }\end{array}$ & $\begin{array}{c}\text { Mean cognitive } \\
\text { score is } 94.54 \\
(S D=12.00)\end{array}$ & $\begin{array}{l}\text {-Stunting and } \\
\text { poor home } \\
\text { environment } \\
\text { quality affect } \\
\text { cognitive } \\
\text { performance } \\
\text {-Study does not } \\
\text { discuss } \\
\text { relationship } \\
\text { between SES } \\
\text { with cognitive } \\
\text { and home } \\
\text { environment } \\
\text { quality }\end{array}$ \\
\hline $\begin{array}{l}\text { Chin et } \\
\text { al. } \\
(2020)\end{array}$ & $\begin{array}{l}\text { Klang } \\
\text { Valley, } \\
\text { Kuala } \\
\text { Lumpur }\end{array}$ & $\begin{array}{l}\text { To assess the } \\
\text { dietary adequacy } \\
\text { and cognitive } \\
\text { performance of } \\
120 \text { homeless } \\
\text { children age } 7-12 \\
\text { years living in } \\
\text { Klang Valley }\end{array}$ & $\begin{array}{c}120 \\
\text { homeless } \\
\text { children age } \\
7-12 \text { years }\end{array}$ & $\begin{array}{l}\text { 24-hours dietary } \\
\text { recall, Raven's } \\
\text { Coloured } \\
\text { Progressive } \\
\text { Matrices (CPM) }\end{array}$ & $\begin{array}{l}70 \% \text { had poor } \\
\text { cognitive } \\
\text { performance }\end{array}$ & $\begin{array}{l}\text { There were no } \\
\text { associations } \\
\text { found between } \\
\text { the energy, iron, } \\
\text { Vitamin B12 } \\
\text { adequacy and } \\
\text { cognitive } \\
\text { performance of } \\
\text { homeless } \\
\text { children except } \\
\text { for zinc } \\
\text { adequacy }\end{array}$ \\
\hline $\begin{array}{l}\text { Poh et al. } \\
\text { (2019) }\end{array}$ & Malaysia & $\begin{array}{l}\text { To determine } \\
\text { the association } \\
\text { between } \\
\text { socioeconomic } \\
\text { and nutritional } \\
\text { status with } \\
\text { cognitive } \\
\text { performance in a } \\
\text { nationally } \\
\text { representative } \\
\text { sample of } \\
\text { Malaysian } \\
\text { children }\end{array}$ & $\begin{array}{c}2406 \\
\text { Malaysian } \\
\text { children } \\
\text { aged } 5 \text { to } 12 \\
\text { years, who } \\
\text { had } \\
\text { participated } \\
\text { in the South } \\
\text { East Asian } \\
\text { Nutrition } \\
\text { Surveys } \\
\text { (SEANUTS) }\end{array}$ & $\begin{array}{c}\text { Self- } \\
\text { administered } \\
\text { questionnaire, } \\
\text { Raven's } \\
\text { Coloured } \\
\text { Progressive } \\
\text { Matrices (CPM), } \\
\text { Anthropometry }\end{array}$ & $\begin{array}{c}\text { About a third } \\
(35.0 \%) \text { of the } \\
\text { children had } \\
\text { above average } \\
\text { non-verbal IQ } \\
\text { while only } 12.2 \% \\
\text { were } \\
\text { categorized as } \\
\text { having } \\
\text { low/borderline } \\
\text { IQ }\end{array}$ & $\begin{array}{l}\text { Children with } \\
\text { severe obesity, } \\
\text { children from } \\
\text { very low } \\
\text { household } \\
\text { income families } \\
\text { and children } \\
\text { whose parents } \\
\text { had only up to } \\
\text { primary level } \\
\text { education had } \\
\text { the highest } \\
\text { prevalence of } \\
\text { low/borderline } \\
\text { non-verbal IQ }\end{array}$ \\
\hline $\begin{array}{l}\text { Sathe \& } \\
\text { Gokhale } \\
(2019)\end{array}$ & Goa, India & $\begin{array}{l}\text { To assess } \\
\text { nutritional status } \\
\text { and intelligence } \\
\text { quotient of } \\
\text { children from } \\
\text { fisherman } \\
\text { community }\end{array}$ & $\begin{array}{c}100 \\
\text { fishermen's } \\
\text { children age } \\
4-6 \text { years, } \\
53 \text { boys and } \\
47 \text { girls }\end{array}$ & $\begin{array}{l}\text { Anthropometry, } \\
\text { 24-hours recall, } \\
\text { The Draw-a- } \\
\text { Person test }\end{array}$ & $\begin{array}{l}\text { The mean IQ } \\
\text { score among the } \\
\text { children was } \\
(105.5 \pm 11.6) \\
\text { under the } \\
\text { moderate } \\
\text { average IQ } \\
\text { category }\end{array}$ & $\begin{array}{c}\text {-Positive } \\
\text { correlation with } \\
\text { occupation and } \\
\text { education of } \\
\text { father, } \\
\text { anthropometry } \\
\text { of the children, } \\
\text { height and MUAC } \\
\text {-Increased } \\
\text { consumption of } \\
\text { soybean and fish } \\
\text { correlated with } \\
\text { better } \\
\text { anthropometric } \\
\text { measurements } \\
\text { and higher IQ } \\
\text { scores }\end{array}$ \\
\hline
\end{tabular}




\begin{tabular}{|c|c|c|c|c|c|c|}
\hline $\begin{array}{c}\text { Tai \& Ali } \\
\text { (2018) }\end{array}$ & $\begin{array}{c}\text { Terengganu } \\
\text { Malaysia }\end{array}$ & $\begin{array}{l}\text { To determine } \\
\text { the relationship } \\
\text { between } \\
\text { breakfast } \\
\text { consumption and } \\
\text { cognitive } \\
\text { performance } \\
\text { among } \\
\text { fishermen's } \\
\text { children }\end{array}$ & $\begin{array}{c}100 \\
\text { fishermen's } \\
\text { children } \\
\text { aged } 7 \text { to } 12 \\
\text { years old }\end{array}$ & $\begin{array}{l}\text { Dietary recall, } \\
\text { Raven's } \\
\text { Coloured } \\
\text { Progressive } \\
\text { Matrices (CPM) }\end{array}$ & $\begin{array}{c}\text {-Grade V } \\
\text { (intellectually } \\
\text { impaired): } 67 \% \\
\text {-Grade IV } \\
\text { (below } \\
\text { average): } 27 \%\end{array}$ & $\begin{array}{l}\text { - There is no } \\
\text { correlation } \\
\text { between } \\
\text { breakfast } \\
\text { consumption } \\
\text { (energy intake, } \\
\text { selected macro- } \\
\text { and } \\
\text { micronutrients) } \\
\text { and cognitive } \\
\text { performance }\end{array}$ \\
\hline $\begin{array}{c}\text { Kim \& } \\
\text { Kang } \\
(2017)\end{array}$ & $\begin{array}{l}\text { Seoul, } \\
\text { Korea }\end{array}$ & $\begin{array}{l}\text { To explore } \\
\text { dietary intake } \\
\text { and cognitive } \\
\text { function in } \\
\text { healthy Korean } \\
\text { children and } \\
\text { adolescents }\end{array}$ & $\begin{array}{l}317 \text { healthy } \\
\text { children and } \\
\text { adolescents }\end{array}$ & $\begin{array}{l}\text { Anthropometry, } \\
\text { food frequency } \\
\text { questionnaire, } \\
\text { cognitive } \\
\text { function tests; } \\
\text { central nervous } \\
\text { system vital } \\
\text { signs (CNSVS) } \\
\text { and Continuous } \\
\text { Performance } \\
\text { Test (CPT) }\end{array}$ & $\begin{array}{l}\text { Cognitive } \\
\text { functions are } \\
\text { closely related } \\
\text { to healthy food } \\
\text { consumptions }\end{array}$ & $\begin{array}{l}\text { Vitamins B1, B6 } \\
\text { and C, rice with } \\
\text { mixed grains, } \\
\text { and mushrooms } \\
\text { are positively } \\
\text { correlated with } \\
\text { better cognitive } \\
\text { function in } \\
\text { contrast to } \\
\text { processed } \\
\text { carbohydrates }\end{array}$ \\
\hline $\begin{array}{c}\text { Haile et } \\
\text { al. } \\
(2016)\end{array}$ & $\begin{array}{c}\text { Goba Town, } \\
\text { Ethiopia }\end{array}$ & $\begin{array}{l}\text { To determine } \\
\text { how nutritional } \\
\text { status and } \\
\text { cognitive } \\
\text { performance are } \\
\text { associated with } \\
\text { academic } \\
\text { performance of } \\
\text { school children } \\
\text { in Goba Town, } \\
\text { south east } \\
\text { Ethiopia }\end{array}$ & $\begin{array}{l}131 \text { school } \\
\text { age } \\
\text { students } \\
\text { from } \\
\text { primary } \\
\text { schools }\end{array}$ & $\begin{array}{c}\text { Sociodemograph } \\
\text { ic, } \\
\text { anthropometry, } \\
\text { 24h dietary } \\
\text { recall, Kaufman } \\
\text { assessment } \\
\text { battery for } \\
\text { children, } \\
\text { Raven's } \\
\text { Coloured } \\
\text { Progressive } \\
\text { Matrices }\end{array}$ & $\begin{array}{l}\text { No actual value } \\
\text { for cognitive } \\
\text { score was } \\
\text { provided }\end{array}$ & $\begin{array}{l}\text {-Weight for age } \\
\text { z-score is } \\
\text { positively } \\
\text { associated with } \\
\text { cognitive and } \\
\text { school } \\
\text { performance } \\
\text {-All cognitive } \\
\text { scores positively } \\
\text { correlated with } \\
\text { mathematic } \\
\text { score }\end{array}$ \\
\hline $\begin{array}{c}\text { Asawa et } \\
\text { al. } \\
(2014)\end{array}$ & $\begin{array}{l}\text { Kutch, } \\
\text { Gujarat, } \\
\text { India }\end{array}$ & $\begin{array}{l}\text { To assess the } \\
\text { intelligence } \\
\text { quotient of } \\
\text { fisherman } \\
\text { schoolchildren of } \\
\text { Kutch, Gujarat, } \\
\text { India }\end{array}$ & $\begin{array}{c}304 \\
\text { fishermen's } \\
\text { schoolchildr } \\
\text { en }\end{array}$ & $\begin{array}{l}\text { Sociodemograph } \\
\text { ic, } \\
\text { anthropometry, } \\
\text { Seguin form } \\
\text { board (SFB) }\end{array}$ & $\begin{array}{c}\text { Evident indicate } \\
\text { low IQ among } \\
\text { schoolchildren } \\
\text { in fishermen } \\
\text { community in } \\
\text { Kutch }\end{array}$ & $\begin{array}{c}\text {-Low SES } \\
\text {-Low education } \\
\text { level of parents } \\
\text {-High body mass } \\
\text { index }\end{array}$ \\
\hline $\begin{array}{c}\text { Nasir et } \\
\text { al. } \\
(2012)\end{array}$ & $\begin{array}{c}\text { Peninsular } \\
\text { Malaysia }\end{array}$ & $\begin{array}{l}\text { To determine } \\
\text { the relationship } \\
\text { between child } \\
\text { feeding } \\
\text { practices, food } \\
\text { habits, and } \\
\text { anthropometric } \\
\text { indicators with } \\
\text { cognitive } \\
\text { performance of } \\
\text { pre-schoolers } \\
\text { aged 4-6 years } \\
\text { old in peninsular } \\
\text { Malaysia }\end{array}$ & $\begin{array}{c}1933 \text { pre- } \\
\text { schoolers } \\
\text { aged } 4-6 \\
\text { years old in } \\
\text { peninsular } \\
\text { Malaysia } \\
\text { based on } \\
\text { department } \\
\text { of statistics } \\
\text { Malaysia, } \\
2000\end{array}$ & $\begin{array}{c}\text { Sociodemograph } \\
\text { ic, } \\
\text { anthropometry, } \\
\text { parent's } \\
\text { nutrition } \\
\text { knowledge, } \\
\text { child feeding } \\
\text { practices, food } \\
\text { habits, Raven's } \\
\text { Coloured } \\
\text { Progressive } \\
\text { Matrices (CPM) }\end{array}$ & $\begin{array}{c}\text {-Mean cognitive } \\
\text { score is } 103.5 \\
\text { (SD=14.4) which } \\
\text { is average. } \\
\text {-Height-for-age } \\
\text { and } \\
\text { consumption of } \\
\text { dinner were } \\
\text { found to } \\
\text { contribute } \\
\text { significantly } \\
\text { towards } \\
\text { cognitive } \\
\text { performance }\end{array}$ & $\begin{array}{l}\text { Height-for-age, } \\
\text { consumption of } \\
\text { dinner and both } \\
\text { short- and long- } \\
\text { term nutritional } \\
\text { status contribute } \\
\text { positively to the } \\
\text { performance }\end{array}$ \\
\hline
\end{tabular}

wt. $=$ weight, ht. $=$ height, SES $=$ socioeconomic status, MUAC $=$ Mid-Upper Arm Circumference

\section{RESULTS}

Proper nutrition is essential for children to enhance their growth and development in terms of physical, cognitive and psychosocial. Childhood malnutrition can negatively affect physical and mental health development and these impacts may last until adolescence or adulthood if no nutritional intervention is taken. Due to the lowincome level of fishermen and seasonality of the fishing activities, fishermen's children are considered as a vulnerable group which have high susceptibility towards food insecurity and malnutrition. The results were focused on the dietary intake and nutritional status among the targeted population; relationship between dietary intake and socioeconomic status; relationship between dietary intake and nutritional status; as well as the relationship between dietary intake, nutritional status and cognitive development. 


\section{Dietary Intake}

Dietary intakes of the fishermen's children have been investigated in this review. There are a total of six reviewed articles that mention dietary intakes. The dietary intakes were documented into three different categories which are energy, macronutrient and micronutrient intakes. Micronutrients that are included in this review are calcium, niacin, iron, vitamin A and vitamin C.

\section{i. Energy intake}

The energy intake of fishermen's children was examined in three studies ${ }^{17-19}$. From those studies, it is demonstrated that the energy intake of these children was significantly lower than the recommended levels. The reduced total energy intake of the fishermen's children could be due to the poor accessibility to food. A study by BakerFrench ${ }^{6}$ reported a high rate of household food insecurity among fishing communities in Bolivia's Northern Amazon which was highly correlated with the socio-economic status of the fishermen households. The amount of money spent to purchase food is dependent on the amount of the fishermen's household income ${ }^{20}$. Low-income level of fishermen constrained their purchasing power and decreased their household accessibility to healthy and nutritious food which eventually resulted in inadequate energy intake among their children. Additionally, some households reduce the amount of food cooked for meals and cook whatever food is available at home as coping strategies in the food insecurity situation ${ }^{21}$.

\section{ii. Macronutrient intake}

Three studies recorded a low level of carbohydrate consumption among the fishermen's children ${ }^{17-19}$. Two studies reported that fat intake among fishermen children was lower than the recommendation $^{17,19}$. Unlike the other macronutrients, the protein intake of the fishermen's children was found to be significantly higher than the recommended levels in three reviewed studies ${ }^{17-19}$. This is due to high consumption of fish and seafood that are more accessible among the fishing community compared to the other high protein sources such as milk products and red meat ${ }^{17}$. This was further supported by the sufficient intake of niacin among the children as niacin is a micronutrient that is found abundantly in fish and shellfish ${ }^{18}$. Besides that, Bandoh \& Kenu ${ }^{22}$ mention in their study that the children in Ghana have their protein requirement met by their diet which consist mainly of fish. Additional to that, a study by Gibson et al. ${ }^{23}$ recorded high consumption of fish especially among the children. This shows that protein intake among the fishermen's children is highly adequate.

\section{iii. Micronutrient intake}

Six reviewed articles mention various micronutrient intake which included calcium, niacin, iron, vitamin A and vitamin C. Three reviewed articles mention that the calcium intake among fishermen's children was found to be lower than the recommended level ${ }^{17-19}$. Calcium is one of the major minerals in the human body which is responsible for proper bone mineralization which includes the formation and maintenance of the body skeleton structure and rigidity. A study by Foo et al. ${ }^{17}$ mentions that only few people prefer or could afford to take milk or other dairy products, which have high calcium content. This can be supported by study from Chua et al. ${ }^{19}$ where they stated that the low accessibility of milk products among the poor might be the cause of low milk and dairy product intake among the fishermen's children. Moreover, the rise in the price of food and non-alcoholic beverages over the past several years has denied access of lowincome groups to milk and dairy products and subsequently deprived poor children of the essential nutrients in milk ${ }^{19}$.

Two reviewed studies show that there is high level intake of niacin intake among the fishermen's children ${ }^{17-18}$. Niacin intake is closely related to the consumption of fish and seafood. Foo et al. ${ }^{17}$ mention that fishing communities are more accessible to fish and seafood. Furthermore, Hanazaki \& Begossi ${ }^{18}$ stated in their study that niacin is a micronutrient that is found abundantly in fish and shellfish.

Next, there are three reviewed studies examining the intake of iron in the fishermen's children ${ }^{17-19}$. Foo et al. ${ }^{17}$ found a significant low level of iron intake compared to the recommended daily dietary iron intake among the adolescents in a fishing community. However, two studies by Hanazaki \& Begossi ${ }^{18}$ and Chua et al. ${ }^{19}$ reported a high iron intake among fishermen households. This claim can be supported by a study by Bandoh \& $\mathrm{Kenu}^{22}$ where they mention that seafood is a good source of iron, a high percentage of children in Ghana consuming flesh food especially fish and other sea foods are likely to increase their stores of iron. Different locations and ethnicity between these studies may influence the level of iron that is needed in their daily life.

There are six reviewed studies mentioning the intake of vitamin $A^{6,17-19,22-23}$. Four of the reviewed studies reported that there is low vitamin A intake ${ }^{6,18,22,23}$. However, two studies by Foo et al. ${ }^{17}$ and Chua et al. ${ }^{19}$ found a significantly higher vitamin $\mathrm{A}$ intake among adolescents in the fishing community compared to the recommendation. Based on a study by Chua et al. ${ }^{19}$, some of the sources of vitamin A are carrots, chicken eggs, chicken, sweet potatoes and Indian Mackerel (Ikan Kembung). Foo et al. ${ }^{17}$ reported that the yearround consumption of raw local fruits and vegetables, and tuber products may contribute to high-level intake of vitamin A among the adolescents in a fishing community in Malaysia. In contrast, Baker-French ${ }^{6}$ mentions that more than one-quarter of respondents did not consume any vegetables or vitamin A rich fruits or vegetables in the specified period. It is also supported by 
Bandoh \& $\mathrm{Kenu}^{22}$ which they mention that the daily consumption of Vitamin A rich foods from both plant and animal sources daily was very low (10\%) among the children where the daily consumption of fruits and vegetables was generally low; vitamin A rich fruits and vegetables - $11 \%$ (27 of 250$)$, other fruits and vegetables- $31 \%$ (79 of 250), respectively. In addition to that, Gibson et al. ${ }^{23}$ found that there is low consumption of vitamin $A$ rich fruit and vegetables.

Vitamin C intake among the fishermen's children was examined in three studies ${ }^{17-19}$. An older study reported low vitamin $\mathrm{C}$ intake among children from fishermen households in Brazil ${ }^{18}$. On the other hand, Foo et al. ${ }^{17}$ and Chua et al. ${ }^{19}$ discovered that there is a higher vitamin $C$ intake than recommended level among adolescents in the fishing community in Malaysia. Additional to that, there is adequate intake of vitamin $\mathrm{C}$ probably due to year-round consumption of raw local fruits and vegetables and tuber products ${ }^{17}$. It can be said that different study regions, dietary patterns and preference of the communities could be leading to the difference in vitamin intakes.

\section{Nutritional status}

Nutritional status of the fishermen's children was examined in seven studies from countries in Southeast Asia, India, South America, Mexico and East Africa ${ }^{6,17,20,23-26}$. Six out of seven studies recorded underweight among the fishermen's children ranged from $14.35 \%$ to $60 \% 6,17,20,23-24,26$. As mentioned in previous study by Foo et al. ${ }^{17}$, the overall nutritional problem is low dietary intake generally leading to thinness in rapidly growing children. Morshy et al. ${ }^{20}$ mention that reduced fish catches, low household income and decreased food security, were among the major causes of high levels of undernutrition among the children in fishing communities. This can be supported by Khor \& Tee $^{24}$ where they mention there is a high prevalence of poverty among the fishing communities.

A study by Foo et al. ${ }^{17}$ shows that there is also prevalence of overweight among the fishermen's children in Malaysia. The results of the study showed that the prevalence of overweight among the children did not exceed $10 \%$. Foo et al. ${ }^{17}$ mention that there is less concern for overweight as the proportion of those at risk of overweight is still small. However, two studies found that about half of the subjects are overweight and obese ${ }^{25,27}$. Murillo-Castillo et al. ${ }^{25}$ mention that $81.5 \%$ of school children regularly consume sweetened beverages, $61.9 \%$ snacks, sweets, and desserts and $53.4 \%$ sweet cereals which probably contributes to overweight and obese. This can be supported by Gibson et al. ${ }^{23}$ where they mention that there is high consumption of sweet and savoury snacks among the children. This shows that the quality of dietary intakes is also important to prevent malnutrition among the children.

\section{Cognitive performance and factors influence}

There are three reviewed studies recorded an average cognitive score ${ }^{28-30}$ while there is one study that shows that children have above average non-verbal $\mathrm{IQ}^{31}$. Studies by Nasir et al. ${ }^{28}$ and Nurliyana et al. ${ }^{29}$ found that mean cognitive score among children in Peninsular Malaysia is within average; 103.5 (SD=14.4) and $94.54(\mathrm{SD}=12.00)$ respectively. A study conducted by Sathe \& Gokhale $^{30}$, also showed an average IQ score among fishermen's children in Goa, India with a mean score of $105.5(S D=11.6)$. Poh et al. ${ }^{31}$ found that $35 \%$ of the children have above average nonverbal IQ with the score between 110-119. In contrast, there are three studies that show low cognitive performance $27,32-33$. A study by Asawa et al. ${ }^{27}$ found that there was a low IQ index among schoolchildren in the fishermen community in Kutch, India. Tai \& $\mathrm{Ali}^{32}$ found that $67 \%$ of the respondents recorded grade $\mathrm{V}$ (intellectually impaired) and $27 \%$ of the respondents recorded grade IV (below average). A study by Chin et al. ${ }^{33}$ found that $70 \%$ had a poor cognitive performance. According to Haile et al. ${ }^{34}$, there was a statistically significant positive correlation between cognitive scores and average academic performance, although no value for cognitive score was provided. A broader perspective has been adopted by Demetriou et al. ${ }^{35}$ who argue that performance varied as a function of tasks or cognitive functions difficulty level. This vary result of cognitive performances is influenced by many factors such as dietary intake, nutritional status, socioeconomic status and also parent's education.

There are four studies that mentioned the relationship between dietary intake and cognitive performance $30,32-33,36$. Based on the study by Sathe \& Gokhale $^{30}$, there are positive correlations between iron, zinc, vitamin B12 and folic acid with performance. In addition to that, Kim \& Kang $^{36}$ mention that vitamin B1, B6 and C are positively correlated with better cognitive function. This can also be supported by Chin et al. ${ }^{33}$ where they found that there is an association between zinc adequacy and cognitive performance. Zinc plays a role in the central nervous system as a neurosecretory and cofactor $^{33}$. Thus, it can cause developmental and intellectual delay due to its deficiency and can have a negative effect on $\mathrm{IQ}^{30}$. Contrary to the finding above, there are two reviewed studies that stated there are no correlation between certain diet adequacy and cognitive performance ${ }^{32-33}$. Tai \& $\mathrm{Ali}^{32}$ stated that there is no correlation between breakfast consumption (energy intake, selected macro- and micronutrient) and cognitive performance. This can be supported by a study by Chin et al. ${ }^{33}$ where they found that there is no association between energy, iron and vitamin B12 and cognitive 
performance. This is due to there being adequate intake for energy, iron, and vitamin B12 among the children but mostly are categorized in the borderline category for their cognitive performance ${ }^{33}$.

Seven of the reviewed studies show there are positive relationships between nutritional status and cognitive development $27-31,34,36$. A study by Nasir et al. ${ }^{28}$ mentions that height-for-age and consumption of dinner were found to contribute significantly towards cognitive performance. In the same study, they found that children with either underweight or overweight/obese have lower academic score compare to children with normal weight ${ }^{28}$. This can be supported by Haile et al. ${ }^{34}$ where they discovered that weight-for-age z-score is positively associated with cognitive and school performance, especially among stunted children where they have impaired behavioural development in early life and have poorer cognitive ability than non-stunted children. Additionally, a study from Nurliyana et al. ${ }^{29}$ also mentions that stunting can affect cognitive performance. Their study found that stunted infants experienced delayed motor developments which particularly inhibit their exploration and learning process from their surroundings which leads to poor cognitive performance ${ }^{29}$. Aside from stunting/underweight, overweight/obese can also affect the cognitive development ${ }^{27,31,36}$. Asawa et al. ${ }^{27}$ mention in their study that overweight or high BMI leads to low cognitive performance. Addition to that, a study by Poh et al. ${ }^{31}$ found that children with severe obesity are more likely to have poor non-verbal IQ. Obesity can harm the brain and compromise performance on intelligence tests ${ }^{27}$. Children with severe obesity may intensify the adverse effect of adiposity where higher adipose tissues can result in higher adipokines production, including leptin, thus increases insulin resistance and therefore promotes hyperinsulinemia, dyslipidemia, inflammation and endothelial dysfunction ${ }^{31}$. Hypertriglyceridemia (one of the dyslipidemias) will result in elevated peripheral leptin levels, which prevent the entry of leptin to the brain, thus harming brain development and consequently lowers cognitive performance ${ }^{31}$. This can be supported by study from Kim \& Kang ${ }^{36}$ where they mention that consumptions of fast foods may diminish cognitive performance.

Socioeconomic status (SES) is one of the concerns among the fishing community due to low and unstable income. Thus, there are six reviewed studies that show the relationship between SES, dietary intake and children's cognitive performance ${ }^{27-28,31,33-35}$. Three reviewed studies had reported that low SES can give an impact toward the children's cognitive development ${ }^{27,31,35}$. This can be supported with study from Nasir et al. ${ }^{28}$, where they mention that socioeconomically disadvantaged children and food habits, consumption of dinner of less than five in a week, influence low cognitive scores and height and weight associated with the performance. Besides that, household financial constraints had been associated with such conditions as limited access to cognitively stimulating materials and limited preschool experiences for children ${ }^{31}$. Thus, have a lesser opportunity in learning and have fewer chances to expose themselves in cognitively challenging tasks causing lack of cognitive stimulation ${ }^{33}$. Furthermore, one reviewed study found that a higher wealth index is associated with better mathematics score of school age children ${ }^{34}$.

Aside from SES, parent's education also reflected the cognitive performance among the children. There are two reviewed studies that show the relationship between parent's education and cognitive performance ${ }^{30-31}$. A positive association was found between the education of fathers and IQ levels of children ${ }^{30}$. Poh et al. ${ }^{31}$ mention that a higher proportion of children whose parents had tertiary education were categorized as having superior non-verbal IQ. Parents with higher education may be more willing to invest time and money in caring for their children ${ }^{37}$. In addition, parents with higher education usually have higher health literacy and engage in quality interactions more frequently with their children, as compared to parents with lower education ${ }^{31}$.

This shows the correlation between nutritional status, dietary intake and cognitive development. Certain essential nutrients are needed to help the development of the children's cognitive. Lacking a certain nutrient due to socioeconomic status may contribute to poor cognitive performance among the fishermen's children.

\section{DISCUSSION}

Based on the work undertaken in this study, opportunities for future research should include assessment of the nutritional status and dietary intake of fishermen children in their middle childhood. Future research should also concentrate on the investigation of the implications of the nutrients which have low levels of intake among the fishermen's children. It is suggested to conduct a longitudinal study on the diet and lifestyles pattern of children from fishing communities to examine their nutritional status more closely. Besides, future research might study the fishermen's children's status of more micronutrients which are crucial for growth and development during childhood such as vitamin $\mathrm{D}$, zinc, iodine and folate. Other possible areas of future research would be to investigate the differences of diet and lifestyle of the fishermen's children during monsoon and nonmonsoon period and its effects on their nutritional status. The effects of heavy metal pollutants and their effects on the health status and cognitive performance of the children also needed to consider as seafood are susceptible to 
contaminants especially mercury. These studies then can be combined with socio-demographic data to assess the economic status and education level of the fishermen's community in Malaysia. Further correlations between nutritional and socio-economic status of fishermen's community with cognitive test scores to investigate factors contributing to such resulted performance hence determining the precise intervention necessary to improve nutritional, socio-economic status and school performance.

\section{CONCLUSION}

In conclusion, most of the studies indicated that poor socioeconomic status, nutritional status and cognitive performance applied to the children and adolescents in children in general and particularly fishing communities, even though they are in different regions. It can be seen that poor socioeconomic status can lead to food insecurity which can result in insufficient of some certain nutrients that are needed for children's development, specifically their cognitive development. The findings of the reviewed studies indicate the need for nutrition education and economic intervention among this vulnerable group. Government and health-related authorities should implement action plan and perhaps invite involvement of NGOs and other third party to introduce various types of interventions to recommend and increase consumption of vegetable, fruit, and dairy products among children fishing communities, while ensuring a method to generate income throughout the year without having to be fully dependent on sea procurements. It also suggests that public forums, nutrition education programmes and motivational programmes be organised in schools as well as in the fishing community, with a view to creating awareness among fishermen's parents about the value of financial security and good quality diets for their children and their impact on the learning process of their children.

\section{Conflict of interest}

The authors declare no potential conflict of interest.

\section{ACKNOWLEDGMENT}

This study was funded under the Fundamental Research Grant Scheme for Research Acculturation of Early Career Researchers (FRGS RACER): RACER/1/2019/SKK06/UMT//1. This study is part of a larger study "Risk assessments of low cognitive performance among fishermen's children in Terengganu, Malaysia".

\section{REFERENCES}

1. Jeejeebhoy KN, Detsky AS, Baker JP. Assessment of nutritional status. Journal of Parenteral and Enteral Nutrition 1990; 14(5): 193-196.
2. Walton E, Allen S. Malnutrition in developing countries. Paediatrics and Child Health 2011; 21(9): 418-424.

3. Mikkila V, Rasanen L, Raitakari OT, et al. Longitudinal changes in diet from childhood into adulthood with respect to risk of cardiovascular diseases: The Cardiovascular Risk in Young Finns Study. European Journal of Clinical Nutrition 2004; 58:1038-1045.

4. McAfee AJ, Mulhern MS, McSorlley EM, et al. Intakes and adequacy of potentially important nutrients for cognitive development among 5-yearold children in the Seychelles Child Development and Nutrition Study. Public Health Nutrition 2012; 15(9).

5. Benton D. The influence of dietary status on the cognitive performance of children. Molecular nutrition \& food research 2010; 54(4): 457-470.

6. Baker-French SR. Food security and nutritional status in fishing communities in Bolivia's Northern Amazon: results of a household survey. Master Thesis, Faculty of Graduate and Postdoctoral Studies (Human Nutrition), University of British Columbia (Vancouver) 2013:1 172.

7. Makame MO, Kangalawe RYM, Salum LA. Climate change and household food insecurity among fishing communities in the eastern coast of Zanzibar. Journal of Development and Agricultural Economics 2015; 7(4): 131-142.

8. Rahman MA, Abka R, Rahman MS, et al. Poverty and food security analysis: A study of fishermen households in a selected area of Bangladesh. Journal of the Bangladesh Agricultural University 2013; 11(2): 293-299.

9. Stanford RJ, Wiryawan B, Bengen DG, et al. Exploring fisheries dependency and its relationship to poverty, A case study of West Sumatra, Indonesia. Ocean and Coastal Management 2013; 84: 140-152.

10. Panikkar KKP, Alagaraja K. Socioeconomic status of fishermen community of Calicut area. Marine Fisheries Information Service, Technical and Extension Series 1981; 33: 2-12.

11. Ujjania NC, Patel AN. Socio-economic status of fishermen community of 
Danti village in Valsad District (Gujarat) India. Emerging Trends in Development Research 2011; 18(1): 25-30.

12. Sivanesan R. Problems and prospects of fisherfolk in Kanyakumari District of Tamilnadu. International Journal of Research in Management \& Business Studies 2014; 1(1): 7-12.

13. Zainudin LM, Zein A, Idris $M H$, et al. Socio-economic profile comparison of fishermen community in Kuala Marang and Seberang Takir, Terengganu, Malaysia. Journal of Sustainability Science and Management 2019; 14(6): 145-157.

14. Nursyazwin M, Zein A. Socio-economic profile and monthly income of fishermen in Marang, Terengganu. Universiti Malaysia Terengganu Journal of Undergraduate Research 2019; 1(1).

15. Yaakob O, Chau QP. Weather downtime and its effect on fishing operation in Peninsular Malaysia. Jurnal Teknologi 2005; 42(A): 13-26.

16. Ishak AM, Zainuddin MZ, Razak FA. Bajet 2016: Nelayan harap peruntukan ditambah. Berita Harian 2015. Available from: http: / /www.bharian.com.my/node/ 91021.

17. Foo LH, Khor GL, Tee ES, et al. Dietary intake of adolescents in a rural fishing community in Tuaran District, Sabah. Malaysia Journal of Nutrition 2006; 12(1): 11-21.

18. Hanazaki N, Begossi A. Does fish still matter? Changes in the diet of two Brazilian fishing communities. Ecology of Food and Nutrition 2003; 42(4-5): 279-301.

19. Shan $\mathrm{CH}$, Ali A, Zakaria NS, et al. Assessment of diet quality and its association with nutritional status among fishermen's children in Terengganu. Malaysia Applied Biology 2018; 47(6): 137-144.

20. Moshy VH, Masenge TJ, Bryceson I. Undernutrition among under-five children in two fishing communities in Mafia Island Marine Park, Tanzania. Journal of Sustainable Development 2013; 6(6): 1.
21. Nik Mohd Sanusi NNN, Ali A, Kamarudin KS, et al. Assessment of food insecurity and food coping strategies among fishermen household during monsoon in Terengganu, Malaysia. Malaysia Applied Biology 2018; 47(6): 1-9.

22. Bandoh DA, Kenu E. Dietary diversity and nutritional adequacy of underfives in a fishing community in the central region of Ghana. BMC Nutrition 2017; 3(2).

23. Gibson E, Stacey N, Sunderland TCH, et al. Dietary diversity and fish consumption of mothers and their children in fisher households in Komodo District, Eastern Indonesia. PLOS ONE 2020; 15(4).

24. Khor GL, Tee ES. Nutritional assessment of rural villages and estates in Peninsular Malaysia II. Nutritional status of children aged 18 years and below. Malaysia Journal of Nutrition 1997; 3: 21-47.

25. Murillo-Castillo KD, Frongillo EA, Corella-Madueño MA, et al. Food insecurity was associated with lower Fruits and vegetables consumption but not with overweight and obesity in children from Mexican fishing communities. Ecology of Food and Nutrition 2020.

26. Capanzana MV, Aguila DV, Gironella GMP, et al. Nutritional status of children ages $0-5$ and $5-10$ years old in households headed by fisherfolks in the Philippines. Archives of Public Health 2018; 76:24.

27. Asawa K, Pujara P, Thakkar JP, et al. Assessment of intelligence quotient among schoolchildren of fishermen community of Kutch, Gujarat, India. International Maritime Health 2014; 65(2): 73-78.

28. Nasir MTM, Norimah AK, Hazizi, AS, et al. Child feeding practices, food habits, anthropometric indicators and cognitive performance among preschoolers in Peninsular Malaysia. Appetite 2012; 58(2): 525530.

29. Nurliyana AR, Shariff ZM, Taib MNM, et al. Early growth and home environment are associated with cognitive development in the first year of life of Malaysian infants. Early human development 2020; 140. 
30. Sathe N, Gokhale D. Intelligence Quotient and Nutritional Status of 4-6 Year Old Children from Fishermen Community of Goa, India. Indian Journal of Public Health Research \& Development 2019; 10(7): 1594-1599.

31. Poh BK, Lee ST, Yeo GS, et al. Low socioeconomic status and severe obesity are linked to poor cognitive performance in Malaysian children. BMC Public Health 2019; 19(4): 541.

32. Tai SW \& Ali A. Breakfast consumption and its relationship with cognitive performance among fishermen's children in Terengganu. Malays. Applied Biology 2018; 47(4): 24-34.

33. Chin KJ, Ali A, Yusof HM, et al. Does dietary adequacy reflect the cognitive performance of children? a study among the homeless children in Klang Valley, Malaysia. IMJM 2020; 19(3): 55-62.

34. Haile D, Nigatu D, Gashaw K, et al. Height for age $z$ score and cognitive function are associated with Academic performance among school children aged 8-11 years old. Archives of Public Health 2016; 74(1): 17.

35. Demetriou A, Kazi S, Makris N, et al. Cognitive ability, cognitive selfawareness, and school performance: From childhood to adolescence. Intelligence 2020; 79.

36. Kim, JY, Kang SW. Relationships between dietary intake and cognitive function in healthy Korean children and adolescents. Journal of lifestyle medicine 2017; 7(1): 10.

37. Dotti Sani GM, Treas J. Educational gradients in parents' child-care time across countries, 1965-2012. Marriage Fam 2016; 78(4):1083-1096. 